\title{
PENGEMBANGAN E-MARKETING SEBAGAI SISTEM INFORMASI LAYANAN PELANGGAN PADA MEGA FLORIST BANDAR LAMPUNG
}

\author{
Tri Darma Rosmalasari ${ }^{1}$, Mega Ayu Lestari ${ }^{2}$, Fajar Dewantoro $^{3}$, Edwin Russel ${ }^{4}$ \\ Universitas Teknokrat Indonesia ${ }^{1,2,3}$ \\ Universitas Lampung ${ }^{4}$
}

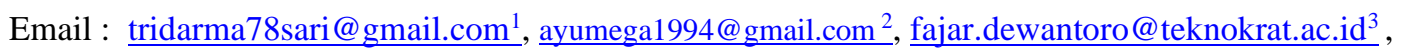
virgo_russels@yahoo.co.id ${ }^{4}$

\begin{abstract}
Received: January 20, 2020
Accepted: Febuary 18, 2020

Abstract

Mega Florist Bandar Lampung is a company engaged in the field of flower board rental and delivery services in the Bandar Lampung area, Mega Florist itself has been established since April 2015. The purpose of this research is to design an e-marketing system and implement an e-marketing system as a customer service at Mega Florist Bandar Lampung. The problem with Bandar Lampung's Mega Florist itself is that there is no system to market board flower rentals, and its marketing still uses brochures, print media, and advertisements so that it requires more costs to market board flower rental services to Mega Florist Bandar Lampung. The system development method uses the waterfall method and the system design uses the UML system design, and the system implementation uses an object-based programming language that is PHP, with Dreamwever and MySQL applications as a database. The result of this research is an online application based on e-marketing built by Mega Florist Bandar Lampung, focused on spreading information on package rental and flower delivery. This web board will present services, facilities, menus, promos and provide convenience for customers in finding information interest rates offered, as well as services in booking board interest rentals.
\end{abstract}

Published : March 15, 2020

Keywords: e-marketing, flower rentals, system

\begin{abstract}
Abstrak
Mega Florist Bandar Lampung adalah perusahan yang bergerak dalam bidang jasa pelayanan penyewaan dan pengiriman bunga papan area Bandar Lampung, Mega Florist sendiri telah berdiri sejak bulan april tahun 2015. Tujuan dalam penelitian ini adalah untuk merancang sistem e-marketing dan mengimplementasikan sistem e-marketing sebagai layanan pelanggan pada Mega Florist Bandar Lampung. Masalah pada Mega Florist Bandar Lampung itu sendiri yaitu belum terdapat sistem untuk memasarkan penyewaan bunga papan, dan pemasarannya masih menggunakan brosur, media cetak, dan iklan sehingga memerlukan biaya yang lebih untuk memasarkan jasa pelayanan penyewaan bunga papan pada Mega Florist Bandar Lampung. Metode pengembangan sistem menggunakan metode waterfall dan perancangan sistem menggunakan perancangan sistem $U M L$, serta implementasi sistem menggunakan bahasa pemograman berbasis objek yaitu PHP, dengan aplikasi dreamwever dan MySQL sebagai database. Hasil dari penelitian ini adalah aplikasi secara online berbasis e-marketing yang dibangun oleh Mega Florist Bandar Lampung, di fokuskan untuk menyebarkan informasi paket penyewaan dan pengiriman bunga papan web ini akan menghadirkan layanan, fasilitas, menu, promo dan memberikan kenyamanan bagi pelanggan dalam mencari informasi bunga papan yang ditawarkan, serta pelayanan dalam pemesanan penyewaan bunga papan.
\end{abstract}

Kata Kunci: e-marketing, penyewaan bunga, sistem

\section{PENDAHULUAN}

Persaingan dunia bisnis di era globalisasi kini semakin ketat (Fadly \& Wantoro, 2019). Untuk perusahaan harus inovatif dan kreatif dalam memasarkan produknya. Pemasaran merupakan salah satu elemen terpenting bagi perusahaan untuk memperkenalkan organisasinya (Sulistiani, 2018). Maka dari itu, kegiatan pemasaran 
harus benar-benar ditangani secara hati-hati. Dikarenakan kegiatan pemasaran sangat erat kaitannya dengan bagaimana berkomunikasi dengan pelanggan, biaya dan kemampuan perusahaan. Komunikasi pemasaran merupakan proses yang dilakukan oleh perusahaan dalam mengkoordinasikan beberapa elemen promosi dan kegiatan pemasaran lainnya sehingga terjalin komunikasi dengan konsumen perusahaan (Belch \& Belch, 2004). Konsep yang secara umum sering digunakan untuk menyampaikan pesan adalah apa yang disebut bauran promosi (promotional mix) disebut bauran promosi karena biasanya pemasaran sering menggunakan jenis promosi yang terintegrasi dalam suatu rencana promosi produk. Kolter (2000) menyebutkan terdapat lima jenis promosi yang biasa disebut sebagai bauran promosi yaitu iklan (advertising), penjualan tatap muka (personal selling), promosi penjualan (sales promotion), hubungan masyarakat dan publisitas (public and public relation) serta pemasaran langsung (direct marketing).

Komunikasi menciptakan adanya interaksi antara perusahaan dengan konsumen. Strategi promosi merupakan salah satu awal dalam rangka mengenalkan produk kepada konsumen dan ini menjadi sangat penting karena berhubungan dengan keuntungan-keuntungan yang akan diperoleh perusahaan. Strategi promosi akan bisa berguna dengan optimal bila didukung dengan perencanaan yang terstruktur dengan baik.

Perusahaan jasa harus dapat merancang strategi promosi yang tepat dalam mencapai tujuan perusahaan, salah satu tujuan perusahaan adalah dapat menarik minat konsumen untuk menggunakan jasa yang ditawarkan. Oleh karena itu untuk menarik perhatian konsumen melakukan pembelian maka perusahaan harus bisa menerapkan suatu strategi pemasaran yang tepat sesuai dengan kondisi pasar yang dihadapi. Keberhasilan strategi pemasaran dipengaruhi oleh beberapa faktor, salah satunya yaitu dengan memilih promosi yang tepat dalam memasarkan jasa.

Internet merupakan pasar global yang sangat besar dengan akses 24 jam tanpa henti sehingga dapat dimanfaatkan sebagai media promosi, menyediakan informasi bagi pelanggan, bahkan menyediakan informasi yang dibutuhkan oleh perusahaan tersebut. Penerapan strategi pemasaran pada perusahaan dapat dilakukan dengan menggunakan teknologi internet yang lebih dikenal dengan istilah E-Marketing (Electronic Marketing). E-Marketing adalah sebuah teknik pemasaran berbasis web dan internet digunakan untuk mencapai sasaran dan mendukung konsep pemasaran yang modern. Dengan sebuah website, perusahaan dapat memasarkan produk atau jasa secara cepat untuk dapat dikenal oleh masyarakat luas mengenai penjelasan produk atau jasa yang lebih terperinci yang dapat membantu pelanggan untuk mendapatkan informasi yang diinginkan (Rudy, 2010).

Mega Florist Bandar Lampung adalah perusahan yang bergerak dalam bidang jasa pelayanan penyewaan dan pengiriman bunga papan area Bandar Lampung, Mega Florist sendiri telah berdiri sejak bulan april tahun 2015. Meskipun sudah tiga tahun berdiri masih banyak masyarakat Bandar Lampung yang belum mengenal Mega Florist. Masalah pada Mega Florist Bandar Lampung itu sendiri yaitu belum terdapat sistem untuk memasarkan penyewaan bunga papan, dan pemasarannya masih menggunakan brosur, media cetak, dan iklan sehingga memerlukan biaya yang lebih untuk memasarkan jasa pelayanan penyewaan bunga papan pada Mega Florist Bandar Lampung, sering kali pelanggan mengalami kesulitan dalam pencarian informasi tentang produk yang dipasarkan oleh Mega Florist Bandar Lampung, hal ini terjadi karena belum adanya website berbasis $e$ marketing pada Mega Florist Bandar Lampung, dan pelanggan harus kelokasi atau ketempat pembuatan papan bunga Mega Florist tersebut untuk mengetahui informasi mengenai produk dan harga penyewaan bunga papan yang ditawarkan.

Alternatif dari masalah diatas, maka akan dibuat aplikasi secara online berbasis e-marketing yang akan dibangun oleh Mega Florist Bandar Lampung ini, di fokuskan untuk menyebarkan informasi paket penyewaan dan pengiriman bunga papan web ini akan menghadirkan layanan, fasilitas, menu, dan promo serta memberikan kenyamanan bagi pelanggan dalam mencari informasi bunga papan yang ditawarkan.

\section{METODE PELAKSANAAN \\ Tempat dan Waktu}

Objek penelitian ini dilakukan di Mega Florist Bandar Lampung, yang beralamatkan di Jl. Sultan Haji Gg. Cempaka No.2 Kota Sepang Bandar Lampung. Mega Florist Bandar Lampung ini sendiri bergerak pada bidang jasa penyewaan papan bunga medan untuk wilayah Bandar lampung dan sekitarnya untuk ucapan berbagai acara. Pelaksanaan pengembangan sistem dimulai dari tahun 2018 dengan melakukan proses pengumpulan data dan identifikasi masalah.

\section{Khalayak Sasaran}

Sasaran dari kegiatan ini yaitu pemilik dan karyawan Mega Florist Bandar Lampung. 


\section{Teknik Pengumpulan Data}

Teknik pengumpulan data adalah cara-cara untuk memperoleh data keterangan-keterangan yang diperlukan dalam penelitian. Teknik pengumpulan data yang digunakan dalam penelitian ini adalah:

1. Wawancara (Interview)

Metode ini dilakukan dengan cara melakukan tanya jawab secara langsung kepada pihak yang terkait terhadap permasalahan yang berhubungan secara langsung. Pada tahap ini peneliti melakukan wawancara kepada karyawan Papan Bunga Mega Florist bagaimana sistem yang berjalan dari penyampaian informasi ke pelanggan sampai dengan laporan.

2. Penyebaran Kuesioner

Metode ini digunakan dengan cara menyebarkan kuesioner kepada masyarakat Bandar Lampung. Hasil dari penyebaran kuesioner ini nantinya akan ditarik kesimpulan tentang pemahamann masyarakat terhadap

3. Tinjauan Pustaka

Penyusun melakukan tinjauan pustaka yaitu dengan mengumpulkan data dari buku-buku referensi, dan sumber-sumber lain yang dapat mendukung dalam pembuatan penelitian ini. Dalam penelitian ini peneliti mencari referensi dari buku dan jurnal-jurnal yang terkait dengan judul.

4. Dokumentasi (Documentation)

Dokumentasi dapat diartikan sebagai sesuatu yang tertulis, tercetak atau terekam yang dapat dipakai sebagai bukti atau keterangan. Dokumentasi dilakukan untuk mengumpulkan data yang bersumber dari dokumen yang ada pada Mega Florist Bandar Lampung yang ada hubungannya dengan masalah yang dibahas. Dalam penelitian ini dokumen yang perlukan yaitu brosur penawaran.

\section{Metode Pengabdian}

Tahapan kegiatan pengabdian merupakan gambaran jalannya kegiatan, sehingga dari tahapan ini nantinya akan tergambar jelas apa yang akan dilakukan, dapat dilihat pada gambar 1 .

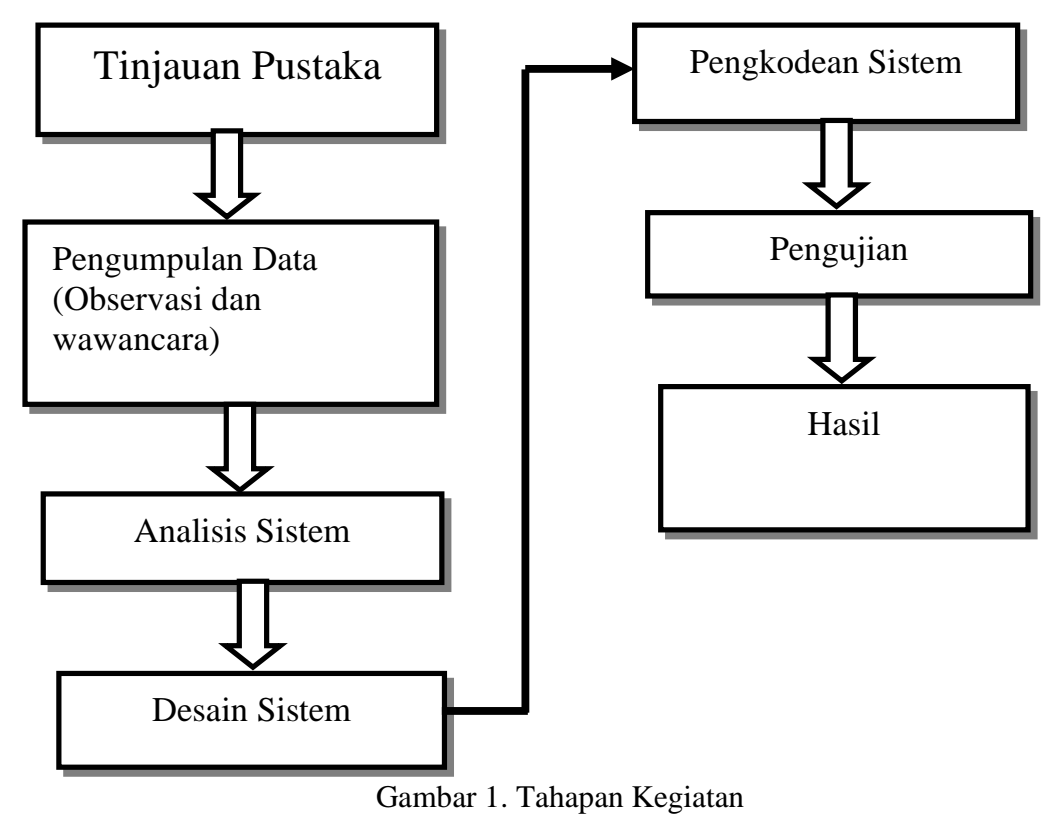

Tahapan ini dibagi menjadi 7 tahap yang dijelaskan sebagai berikut :

Tahap 1: Tinjauan Pustaka

Tinjauan pustaka didapat dari jurnal, dan buku, dilakukan untuk mendapatkan data yang valid. Setelah itu dilakukan identifikasi terhadap objek kegiatan dengan definisi masalah dan lingkup penelitian.

\section{Tahap 2: Pengumpulan Data}

Pada tahap ini dilakukan dengan dokumentasi dan wawancara, lalu dilakukan identifikasi terhadap objek kegiatan dengan mengkaji penelitian terdahulu, definisi masalah dan lingkup penelitian. 
Tahap 3: Analisis Sistem

Pada tahap ini dilakukan analisis sistem untuk mengidentifikasi masalah menggunakan analisi PIECES yang tediri dari Performace (Kinerja), Information (Informasi), Economy (Ekonomi), Control (Pengendalian), Efficiency (Efisiensi), Service (Pelayanan) dan juga melakukan analisis kebutuhan serta kelayakan. Hasil dari analisis tersebut yang nantinya akan menjadi acuan dalam penerapan E-Marketing pada jasa penyewaan papan Bunga Mega Florist.

Tahap 4: DesainSistem

Dalam tahapan ini akan dibentuk suatu arsitektur sistem berdasarkan persyaratan yang telah ditetapkan. Serta mengidentifikasi dan menggambarkan abstraksi dasar sistem perangkat lunak dan hubungan-hubungannya.

Tahap 5: Pengkodean

Melakukan implementasi sistem yang ingin dilakukan menggunakan aplikasi Dreamweaver dan MySQL.

Tahap 6: Pengujian Sistem

Rancangan pengujian, penulis menggunakan metode pengujian blackbox (blackbox testing). Blackbox testing adalah salah satu metode pengujian perangkat lunak yang berfokus pada sisi fungsionalitas, khususnya pada input dan output aplikasi (apakah sudah sesuai dengan apa yang diharapkan atau belum).

Tahap 7: Hasil

Berisi kesimpulan terhadap pengujian sistem menggunakan metode blackbox testing. Sehingga akan ditarik kesimpulan bahwa fungsionalitas sistem berjalan dengan baik atau tidak, terhadap E-Marketing penyewaan papan Bunga Mega Florist.

\section{HASIL DAN PEMBAHASAN}

\section{Desain Sistem}

Desain sistem merupakan tahap yang menentukan proses dan data yang diperlukan oleh sistem baru. Desain sistem ini merupakan gambaran secara menyeluruh mengenai urutan pengolahan data dari persiapan desain sistem sampai menghasilkan laporan yang dibutuhkan.

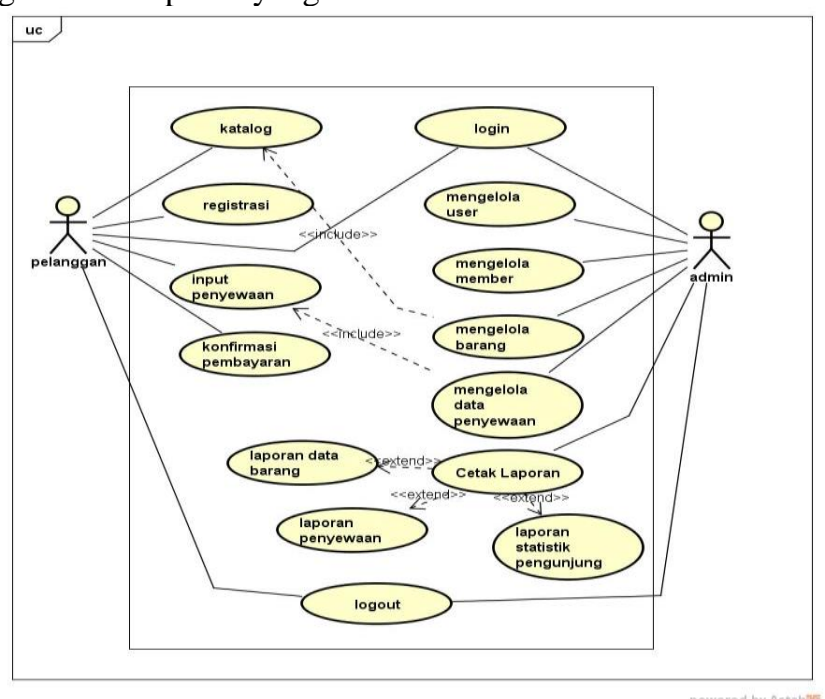

Gambar 2. Use Case Diagram

\section{Implementasi Sistem}

Bagian ini menjelaskan tentang pembuatan program pemasaran, dengan memberikan contoh tampilan form, Implementasi merupakan tahap dimana sistem siap dioperasikan pada tahap sebenarnya, sehingga akan diketahui apakah sistem yang akan dibuat benar-benar dapat menghasilakan tujuan yang diinginkan.

1) Tampilan Form Pendaftaran

Form pendaftaran yang dirancang untuk memudahkan pelanggan dalam melakukan pendaftaran pemesanan yang tertera dalam website. Pelanggan bisa langsung mengisi data diri yang telah 
disediakan melalui form pendaftaran dengan syarat dan ketentuan yang berlaku di dalam form pendaftaran. Adapun tampilannya sebagai berikut pilihan menu pendaftaran untuk menjadi member.

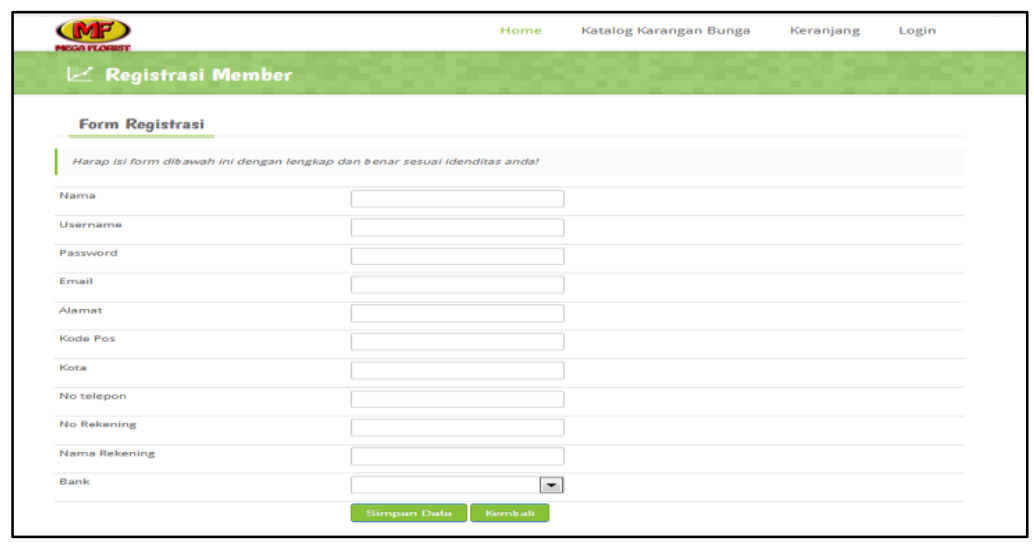

Gambar 3. Tampilan Form Pendaftaran

2) Halaman Beranda

Tampilan beranda adalah awal ketika user membuka website. Tampilan halaman beranda dapat dilihat pada gambar 4.

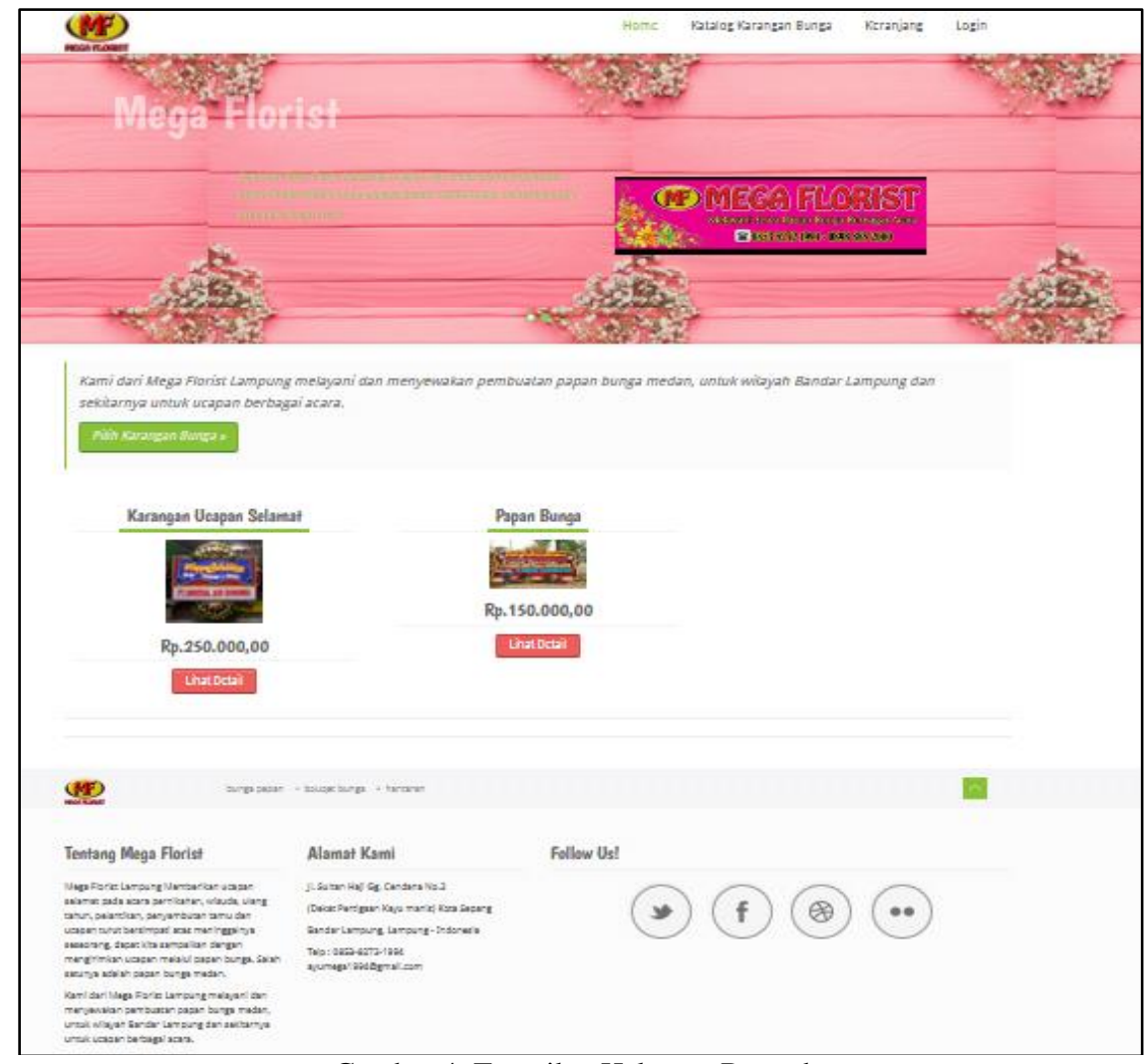

Gambar 4. Tampilan Halaman Beranda

3) Tampilan Halaman Input Data Barang

Merupakan menu yang berfungsi untuk menginputkan data barang. Adapun tampilannya dapat dilihat pada gambar 5 . 


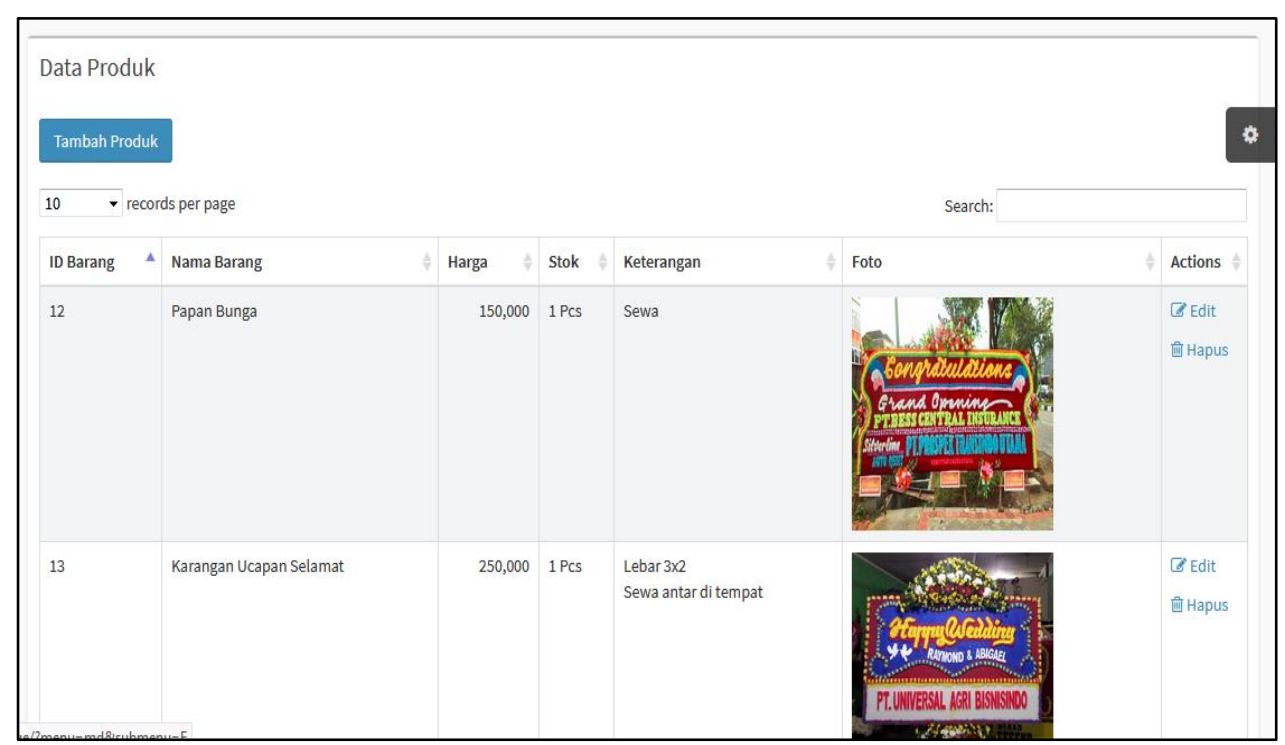

Gambar 5. Tampilan Halaman Input Data Barang

\section{Pengujian Sistem}

Pengujian sistem dilakukan untuk menjamin kualitas dan juga mengetahui kelemahan dari sistem. Tujuan dari pengujian ini adalah untuk menjamin bahwa perangkat lunak yang dibangun memiliki kualitas yang handal, yaitu mampu merepresentasikan kajian pokok dari spesifikasi, analisis, perancangan dan pengkodean dari perangkat lunak itu sendiri. Dalam pengujian perangkat lunak ini penulis menggunakan suatu metode pengujian yang berfokus pada persyaratan fungsional perangkat lunak yang dibangun. Metode yang diambil adalah metode pengujian Black Box. Pengujian Black Box adalah pengujian yang sistemnya tanpa memperhatikan struktur logika internal perangkat lunak (Rosa dan Shalahuddin, 2014). Metode ini digunakan untuk mengetahui apakah perangkat lunak berfungsi dengan benar.

\section{KESIMPULAN}

Bedasarkan hasil pembahasan yang telah dilakukan, maka dapat disimpulkan sebagai berikut :

1. Pemodelan system e-marketing menggunakan pemodelan berorientasi objek dengan alat $U M L$, yang menghasilkan sebuah model sistem baru untuk Mega Florist Bandar Lampung.

2. Mengimplementasikan system e-marketing pada Mega Florist Bandar Lampung ini menggunakan aplikasi Dreamweaver dan database MySQL. Selanjutnya dimplementasikan dalam web. Hasilnya sebuah web dengan nama batikcendekiawan.com.

\section{REFERENSI}

Rosa, A.S dan M. Shalahuddin. 2014. Rekayasa Perangkat Lunak (terstruktur dan berorientasi objek). Modula, Bandung. Belch, George E, Michael A. Belch. 2004.Advertising and promotion: An Integrated Marketing communication Perspective. Sixth Edition. New York: McGraw-Hill.

Fadly, Muhtad \& Wantoro, Agus. 2019. Model Sistem Informasi Manajemen Hubungan Pelanggan dengan Kombinasi Pengelolaan Digital Asset untuk Meningkatkan Jumlah Pelanggan. Prosiding Seminar Nasional Darmajaya.

Kotler, Philip. 2002. Manajemen Pemasaran. Edisi Millenium, Jilid 2, PT Prenhallindo: Jakarta.

Rudi. 2010. Pemasaran E-Marketing Bagi Produk Kecantikan. Yogyakarta.

Setiyaningrum. 2015. Prinsip-Prinsip Pemasaran. Edisi 1. Yogyakarta

Suherman Kusniadji. 2016. Strategi pemasaran dalam kegiatan pemasaran produk Consumer Goods (Studi Kasus pada PT Expand Berlian Mulia di Semarang). Online

Solichin. 2010. Pemograman Web Dinamis Menggunakan PHP dan MySQL. Andi. Yogyakarta

Sommerville, Ian. 2011. Sofware Enginering. Includes Index. Jakarta

Sulistiani, Heni. 2018. Pengukuran Efektifitas Strategi Pemasaran Secara Online.

Sunyoto. 2014. Konsep Dasar Riset Pemasaran \& Prilaku Konsumen. Cetakan Pertama. Yogyakarta. 